Reprod. Nutr. Dévelop., 1983, 23 (5), 793-816.

\title{
Utero-ovarian relationships in placental mammals : role of uterus and embryo in the regulation of progesterone secretion by the corpus luteum. A review
}

\author{
Marie-Claire LEVASSEUR
}

Station centrale de Physiologie animale, I.N.R.A., 78350 Jouy-en-Josas, France.

Summary. The role of the uterus and that of the embryo in regulating luteal progesterone secretion appear to differ greatly, depending on the mammal. However, the situation is analogous in some mammals. The main role of luteal progesterone is to permit the establishment and maintenance of pregnancy, and there appears to be a relationship between the type of placenta and the uterine and embryonic modes of regulating luteal activity.

When placentation is endotheliochorial (carnivores), the corpus luteum is active over a remarkably long period; the uterus does not have any limiting action in any of the species studied and the presence of an embryo does not profoundly modify luteal progesterone secretion.

When placentation is epitheliochorial (artiodactyls), hysterectomy, like the presence of an embryo in the uterus, considerably prolongs luteal activity in all the species studied. The uterus limits the duration of progesterone secretion by producing luteolytic PGF $_{2 \alpha}$. The embryo maintains progesterone secretion by acting directly on the uterus, causing a change in the synthesis of prostaglandins ; this change eventually favors the synthesis of luteotropic PGE's. Moreover, the embryo secretes LH-like and possibly prolactin-like luteotropic factors.

When placentation is hemochorial (rodents, lagomorphs, higher primates), the uterus plays a slight role or none at all in regulating luteal activity in all the species studied. The presence of an embryo prolongs and often increases progesterone secretion. The embryo acts in two ways : (a) by causing decidual tissue to form in the endometrium ; this tissue secretes the luteotropic factors, uterine "prolactin " and sometimes PGE, and (b) by secreting an $\mathrm{LH}$-like chorionic hormone that is produced in large quantities in primates.

The endocrine relationships between ovary and uterus are not unidirectional. While changes in the uterus depend on ovarian steroids, the uterus, in return, can modulate ovarian activity. These relationships are modified by pregnancy because the embryo acts directly on the uterus and directly or indirectly on the ovary. But the study of endocrine relationships between ovary and uterus reveals such a diversity of situations that observations made in one species are difficult to transpose to another, even closely related, species.

However, known facts concerning the role of uterus and embryo in the 
regulation of luteal progesterone secretion can be grouped according to three major types of uterus-embryo relationships : epitheliochorial, endotheliochorial or hemochorial placentation (see Wimsatt, 1962). The present article attempts to define these groupings.

\section{Privileged vascular connections between ovary and uterus}

Before examining the role of uterus and embryo, it is necessary to recall the nature and importance of vascular connections between ovary and uterus.

In all studied mammals, a more or less large area of contact has been found between the utero-ovarian vein and the ovarian artery; this area permits the privileged counter current transfer of steroids and prostaglandins lewe : McCraken et al., 1972 ; guinea-pig, rat, hamster, rabbit, mare, ewe, sow : Del Campo and Ginther, 1972, 1973 ; macaque : Ginther et al., 1974 ; cow : Hixon and Hansel, 1974 ; Krzymowski et al., 1981 ; sow : Krzymowski et al., 1982 ; woman: Bendz, 1977, 1982 ; Bendz et al., 1979; dog, cat : Del Campo and Ginther, 1974). The lymphatic system, tubal vessels and vascular anastomoses also contribute to the establishment of privileged relationships between uterus and ovary (ewe : Lamond and Drost, 1973 ; Alwachi, Bland and Poyser, 1981 ; sow : Kotwica, 1980).

The whole of these particular vascular arrangements, for exámple, leads to the observation that the genital tract tissues located next to the corpus luteum contain more progesterone than those located on the opposite side, there being a concentration gradient, moreover, related to the proximity of the corpus luteum (cow : Pope, Maurer and Stormshak, 1982).

The integrity of vascular connections between ovary and uterus is crucial to the normal progression of ovarian activity. In mammals in which uterine $\mathrm{PGF}_{2 \alpha}$ plays an important role in luteolysis, the simple interruption of normal vascular connections between uterus and ovary prolongs luteal activity (guinea-pig : Bland and Donovan, 1969 ; Fischer, 1971 ; rat : Clemens, Minaguchi and Meites, 1968 ; $\mathrm{O}^{\prime}$ Shea and Lee, 1973 ; sow : Torres and First, 1975 ; ewe : Inskeep and Butcher, 1966 ; Dobrowolski and Hafez, 1970 ; Baird and Land, 1973).

In woman, ligature or cauterization of the Fallopian tubes, while it has no great effect on the length of the menstrual cycle, seems to increase the frequency of luteal failure, reducing preovulatory follicle oestradiol secretion and the level of LH ovulatory surge (Radwanska, Berger and Hammond, 1979 ; Alvarez-Sanchez et al., 1981).

When pregnancy is established, these privileged relationships between ovary and uterus assume considerable importance as the embryo causes luteal phase progesterone levels to be maintained. Furthermore, the fact that privileged relationships exist between ovary and uterus should make us cautious as to conclusions drawn from experiments in which drugs are injected by a general route and the significance of the circulating hormone levels observed.

Finally, basic differences in vascular connections between ovary and uterus do not appear to be the cause of interspecies differences in endocrine relationships between these organs. 


\section{Uterine regulation of the length of the oestrous or menstrual cycle}

The effects of hysterectomy on progesterone secretion by corpus luteum vary considerably among mammals. These differences have demonstrated the role of uterus in regulating the length of the cycle. Five different cases have been observed (fig. 1):
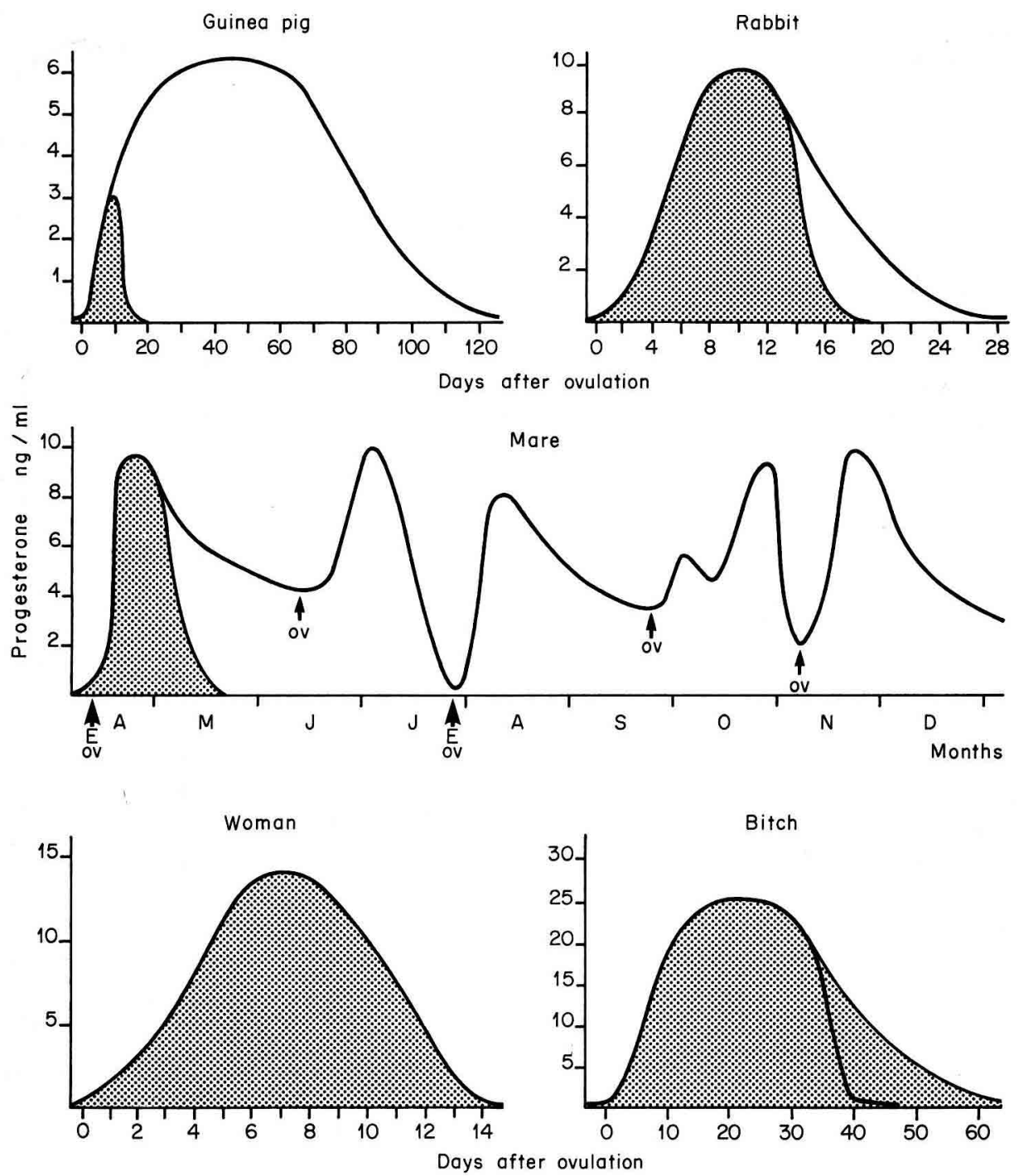

FIG. 1. - Effects of hysterectomy on activity of the corpus /uteum. Diagram showing changes in luteal progesterone secretion during a normal cycle (shaded area) or after hysterectomy in five mammals belonging to the five observed groups. The progesterone profile of rabbit is observed after sterile mating. In hysterectomized mare, the levels of circulating progesterone vary greatly. Sporadic ovulations are accompanied (I E, OV) or not ( 1 OV) by oestrous behaviour. 
1) hysterectomy is followed by a strong increase in progesterone secretion and a considerable prolongation of luteal activity, as in guinea-pig (Poyser and Horton, 1975) ;

2) hysterectomy is followed by luteal maintenance of progesterone secretion for several months, as in ewe, cow, sow and mare (see Anderson, Bland and Melampy, 1969 ; Stabenfeldt et al., 1974 ; Schirar and Martinet, 1982) ;

3) hysterectomy slows down the gradual drop in the circulating progesterone level that marks the end of the luteal phase as in pseudopregnant rat, mouse, hamster and rabbit (mouse, hamster : De Feo, 1967 ; Duby et al., 1969 ; Crister, Rutledge and French, 1981 ; rat : De Feo, 1967 ; Rothchild and Gibori, 1975 ; De Greef, Dullaart and Zeilmaker, 1976 ; rabbit : Hilliard et al., 1974 ; Satoh et al., 1980) :

4) hysterectomy has no effect either on the length of the activity of corpus luteum or on the amounts of progesterone secreted as in ferret, mink, spotted skunk and European badger (Deanesly and Parkes, 1933 ; Canivenc, Bonnin and Lajus, 1966 ; Duby, 1972 ; Mead and Swannack, 1978 ; Canivenc, Bonnin and Relexans, 1962), or in woman and macaque (Neill, Johansson and Knobil, 1969 ; Doyle et al., 1971 ; Fraser et al., 1973 ; Castracane, Moore and Shaikh, 1979) ;

5) hysterectomy reduces the duration of luteal activity by hastening the drop in progesterone secretion at the end of the luteal phase as in dog (Hadley, 1975b ; Baker et al., 1980).

When hysterectomy extends the activity of corpus luteum, it suppresses the $\mathrm{PGF}_{2 \alpha}$ source involved in luteolysis. The inhibition of prostaglandin synthesis by indomethacin has the same effects on progesterone secretion as hysterectomy (rat, hamster : Lau, Saksena and Chang, 1975 ; rabbit: Satoh et al., 1980 ; guinea-pig: Horton and Poyser, 1973; Poyser and Horton, 1975; mouse : Crister, Rutledge and French, 1981 ; sow : Kraeling, Rampacek and Kiser, 1981 ; ewe : Kann and Lacroix, 1982).

In ewe (fig. 2), cow, sow and mare, the end of the oestrous cycle is
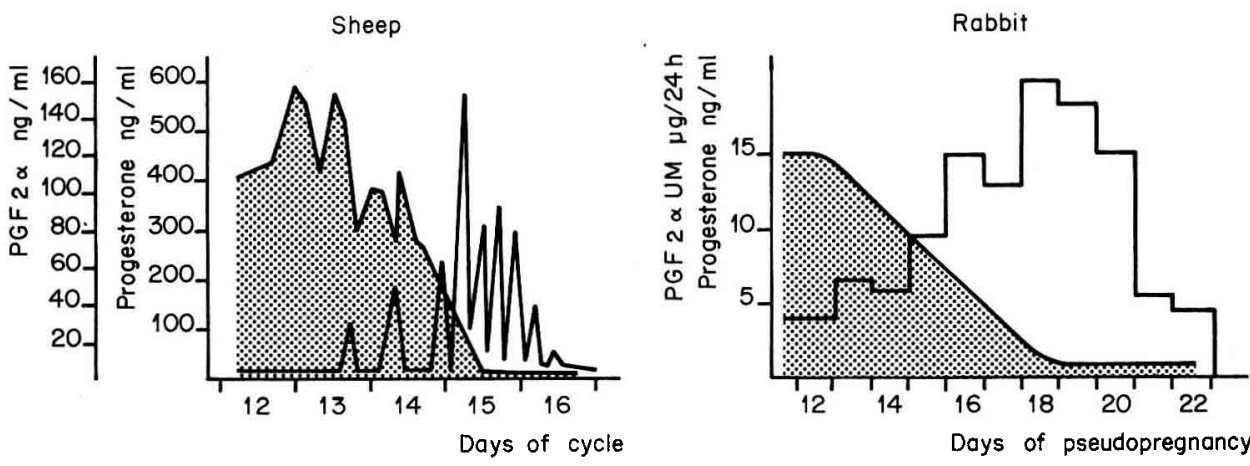

FIG. 2. - Functional luteolysis and uterine $\mathrm{PGF}_{2 \alpha}$. Diagram showing changes in luteal progesterone secretion and uterine $\mathrm{PGF}_{2 r}$ secretion at the end of the luteal phase in ewe and rabbit. Ewe : frequent assays in the blood of the utero-ovarian vein show surges of $\mathrm{PGF}_{2 \alpha^{*}}$. Rabbit : assay of the PGF $_{2 \alpha}$ metabolite in uterine collected over $24 \mathrm{~h}$ shows an overall increase in PGF $_{2 \alpha}$ production. 
characterized by large surges of uterine $\mathrm{PGF}_{2 \alpha}$. But, while the gradual decline in the level of circulating progesterone is certainly related to small surges of $\mathrm{PGF}_{2 \alpha}$, large amounts of $\mathrm{PGF}_{2 \alpha}$ are not released until the progesterone level is very low ; these large surges of $\mathrm{PGF}_{2 \alpha}$ thus occur after progesterone secretion has stopped (functional luteolysis) (ewe : Thorburn et al., 1973 ; Peterson et al., 1976 ; cow : Peterson et al., 1975 ; Kindahl et al., 1976a ; sow : Gleeson, Thorburn and Cox, 1974 ; Moeljono et al., 1977 ; Shille et al., 1979 ; mare : Stabenfeldt et al., 1981). The case of rat, rabbit and guinea-pig is the same (Weems et al., 1975 ; Satoh et al., 1980 ; Blatchley et al., 1972) (fig. 2). The demonstration of endogenous $\mathrm{PGF}_{2 \alpha}$ surges in ewe 36 to $72 \mathrm{~h}$ after induction of functional luteolysis by a prostaglandin analog confirms that prostaglandin production by the uterus at the end of the cycle is, at least in part, a result of the drop in the level of circulating progesterone (Challis et al., 1976).

When hysterectomy reduces the duration of luteal activity, it would seem that the suppression of uterine prostaglandins $E\left(P G E_{1}\right.$ or $\left.E_{2}\right)$ is involved. In fact, all mammalian uteri secrete $\mathrm{PGE}_{1}$ or $\mathrm{E}_{2}$ as well as $\mathrm{PGF}_{2 \alpha^{*}}$. Prostaglandins $\mathrm{E}$ are luteotropic, inhibiting the luteolytic action of $\mathrm{PGF}_{2 \alpha}$. In ewe, while intrauterine infusion of $\mathrm{PGF}_{2 \alpha}$ results in early luteolysis, the infusion of $\mathrm{PGE}_{2}$, and especially of $\mathrm{PGE}_{1}$, entrains the maintenance of progesterone secretion (Nett, McClellan and Niswender, 1976; Magness et al., 1981; Huie et al., 1981). Simultaneous infusion of $\mathrm{PGF}_{2 \alpha}$ and $\mathrm{PGE}_{2}$ prevents the drop in progesterone level induced by $\mathrm{PGE}_{2 \alpha}$ infused alone (Henderson, Scaramuzzi and Baird, 1977) (fig. 3).

Besides the $\mathrm{PGF}_{2 \alpha}$ surges characteristic of luteolysis in pseudopregnant rabbit, the endometrium produces almost identical quantities of $\mathrm{PGF}_{2 \alpha}$ and $\mathrm{PGE}_{2}$. On the other hand, in pregnant rabbit, $\mathrm{PGE}_{2}$ production is increased by 100 from day 13-14 of pregnancy. When embryos and placentas are removed before this

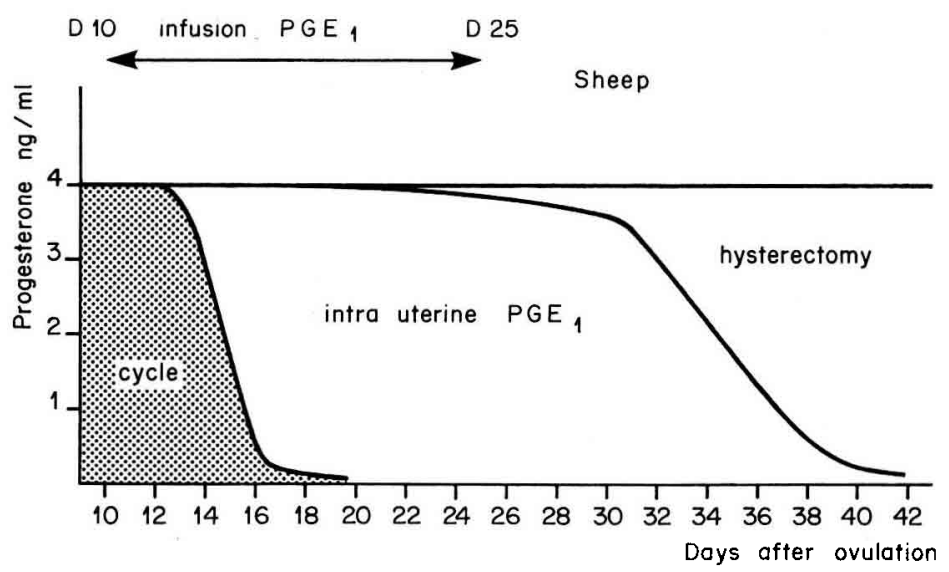

FIG. 3. - Luteotropic action of $\mathrm{PGE}_{1}$. Diagram showing changes in luteal progesterone secretion in ewe : at the end of a cycle, the circulating progesterone level drops suddenly. Intrauterine infusion of $\mathrm{PGE}_{\uparrow}$ for 15 days entrains the maintenance of progesterone secretion during treatment and considerably extends the secretory activity of the corpus luteum after treatment is stopped. Contrary to observations in mare (fig. 1), hysterectomy results in true maintenance of progesterone secretion. 
time, progesterone secretion progresses as in pseudopregnancy; when they are removed later, a sudden drop in luteal progesterone secretion occurs (Browning and Wolf, 1981 ; Lytton and Poyser, 1982).

In bitch, the length of pregnancy and pseudopregnancy are comparable, the progesterone levels are identical or only slightly different in both cases, and PGE is very abundant in the uterine vein at the end of pregnancy, but PGF $_{2 \alpha}$ is practically absent (Smith and McDonald, 1974 ; Gerber, Hubbard and Nies, 1979). It is thus possible that the uterus produces increasingly large amounts of PGE on which the corpus luteum comes to depend heavily, although, at the same time, both luteotropic hormones, $\mathrm{LH}$ and prolactin, are indispensible for its normal activity (Concannon, 1980, 1981).

When hysterectomy has no effect on progesterone secretion, the uterus, nevertheless, does produce prostaglandins $\mathrm{PGF}_{2 \alpha}$ and PGE, but the drop in the circulating progesterone level is not associated to an increase in prostaglandins $\mathrm{F}_{2 \alpha}$ (macaque : Demers, Yoshinaga and Greep, 1974 ; woman : Downie, Poyser and Wunderlich, 1974 ; Singh, Baccarini and Zuspan, 1975 ; Levitt, Tobon and Josimovich, 1975 ; Demers et al., 1975 ; Maathuis, 1978 ; Maathuis and Kelly, 1978). Only a small increase in the level of circulating $\mathrm{PGF}_{2 \alpha}$ is observed when the progesterone level is very low (woman : Kindahl et al., 1976b ; Koullapis and Collins, 1980). The $\mathrm{PGF}_{2 \alpha}$ produced by the ovary itself might then be involved in luteolysis. In macaque, indomethacin treatment causes the amounts of PGF ${ }_{2 \alpha}$ measured in the blood of the ovarian vein to decrease rapidly as the progesterone level rises (Auletta, Agins and Scommegna, 1978).

The putative involvement of ovarian $\mathrm{PGF}_{2 \alpha}$ in luteolysis has been observed in mouse, a species in which hysterectomy only reduces the rate of functional luteolysis ; indomethacin treatment of pseudopregnant hysterectomized females slows down the drop in circulating progesterone even more and retards the reappearance of oestrus (Crister, Rutledge and French, 1981). On the contrary, in sow, in which the preponderant role of uterine $\mathrm{PGF}_{2 \alpha}$ has been demonstrated by hysterectomy, indomethacin treatment of hysterectomized females does not change the secretion of progesterone by corpus luteum (Kraeling, Rampacek and Kiser, 1981).

In all mammals, $\mathrm{PGF}_{2 \alpha}$ is involved in luteolysis at the end of the cycle (see Thibault and Levasseur, 1979). The uterus of all mammals produces prostaglandins $P G F_{2 \alpha}$ and $P G E_{1}$ and/or $E_{2}$. The very diverse consequences of hysterectomy in different mammals do not arise from fundamental differences in uterine ability to synthesize prostaglandins.

These differences in the effects of hysterectomy appear to have two causes :

1) the main source of the $\mathrm{PGF}_{2 \alpha}$ involved in luteolysis, uterine when hysterectomy prolongs progesterone secretion and ovarian when hysterectomy does not affect luteal activity, and

2) the nature of the prostaglandins produced by the uterus: $\mathrm{PGF}_{2 \alpha}$ is mainly produced when hysterectomy extends luteal activity, and $P G E_{1}$ or $E_{2}$ is probably produced when hysterectomy reduces this activity. However, this hypothesis must be confirmed. 


\section{Effects of the presence of an embryo in the uterus on luteal progesterone secretion}

Due to its production of progesterone, the corpus luteum plays a fundamental role in all placental mammals, ensuring the development of the uterus so that pregnancy can be established and progress. The activity of the corpus luteum is always transitory, but the existence of a " cyclic " corpus luteum having limited activity as compared to a " pregnancy " corpus luteum poses the dual problem of factors causing the corpus luteum to disappear at the end of the cycle and those maintaining it when pregnancy is established. In all studied mammals, a corpus luteum is maintained throughout pregnancy. However, experiments with ovariectomy during pregnancy have shown that mammals can be divided into two groups :

1) those in which the corpus luteum is the only (or main) source of progesterone throughout pregnancy ; ovariectomy always entrains a rapid drop in circulating progesterone and almost always abortion (e.g. rat, mouse, hamster, rabbit, sow, cow, goat, bitch, fox, mink) ;

2) those in which the placenta takes over from the ovary, ensuring most of the progesterone secretion ; ovariectomy then causes only a slight, often temporary, decrease in the level of circulating progesterone and pregnancy continues to term (e.g. woman, macaque, guinea-pig, ewe, cat). The secretion of progesterone by the corpus luteum is then qualitatively and quantitatively of secondary importance. In studying the effects of the presence of an embryo on luteal progesterone secretion, we are only concerned with the period during which luteal progesterone is indispensible.

This implies that the length of pregnancy, compared to the length of the cycle or of pseudopregnancy, only has true significance in mammals of the first group, and that examination of the circulating progesterone level must take into account the eventual role of the placenta.

In view of these factors, the existence of a cyclic corpus luteum different from a gestational one does not raise a question in all mammals, and the nature of the relationships existing between mother and embryo is a factor that may be taken into account when considering the differences observed between species.

\section{Species with endotheliochorial placentation.}

Among studied mammals, this type of placenta characterizes carnivores. In this species, luteal progesterone secretion is comparable during the luteal phase of a sterile cycle (pseudopregnancy) and during pregnancy (fig. 4).

When the placenta supplies no progesterone, pseudopregnancy lasts exactly as long as pregnancy, and the profile of the circulating progesterone level is almost the same (bitch : Smith and McDonald, 1974 ; ferret : Carlson and Rust, 1969 ; Heap and Hammond, 1974 ; fox : Møller, 1973a ; Bonnin, Mondain-Monval and Dutourné, 1978 ; mink : Møller, 1973b ; Allais and Martinet, 1978 ; striped skunk: Wade-Smith et al., 1980). Ovariectomy during pregnancy then always causes a sudden drop in the level of circulating progesterone and abortion (bitch : Sokolowski, 1971 ; fox : Møller, 1974a ; mink: Møller, 1974b). When the 

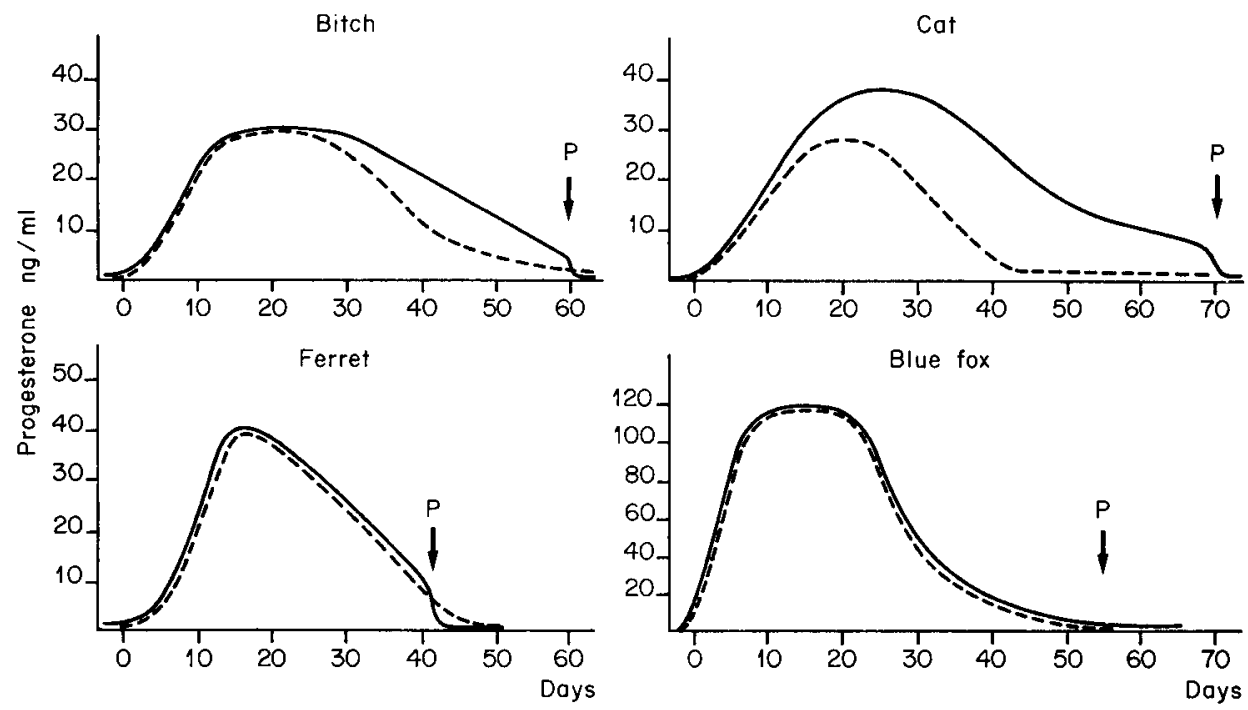

FIG. 4. - Progesterone secretion in carnivores. Diagram showing changes in circulating progesterone during pregnancy (-) and after sterile mating (----) in four carnivores. In dog, ferret and blue fox, the length of pregnancy and of pseudopregnancy is the same; the levels of circulating progesterone are identical or vary little in both cases. In cat, pregnancy last longer than pseudopregnancy. Progesterone produced by the foetoplacental unit accounts for the increase in circulating progesterone levels during pregnancy.

$P=$ parturition .

placenta is involved in progesterone secretion, pregnancy lasts longer than pseudopregnancy and the higher levels of circulating progesterone are maintained longer, but ovariectomy of the pregnant female no longer results in abortion when normal term of pseudopregnancy is reached. This is the case in cat (Gros, 1936 ; Verhage, Beamer and Brenner, 1976 ; Malassiné and Ferré, 1979), and perhaps in European badger (Bonnin, Canivenc and Charron, 1981), lion, wolf and puma (Seal et al., 1979 ; Schmidt et al., 1979 ; Bonney, Moore and Jones, 1981).

Except for dog, hysterectomy in studied carnivores has no effect on the activity of the corpus luteum (ferret, mink, spotted skunk, European badger). Moreover, luteal progesterone secretion has common characteristics in all studied females, i.e. the maximal level is often high and is reached rather slowly (10-20 days). The activity of corpus luteum decreases slowly and continually. Finally, the corpus luteum is active for 1 to 2 months or more (cat : Verhage, Beamer and Brenner, 1976 ; dog : Smith and McDonald, 1974 ; Concannon, Hansel and Visek, 1975 ; Hadley, 1975a ; blue fox : Møller, 1973a ; red fox : Bonnin, Mondain-Monval and Dutourné, 1978 ; coyote : Stellflug et al., 1971 ; wolf : Seal et al., 1979 ; puma : Bonney, Moore and Jones, 1981 ; lion : Schmidt et al., 1979 ; ferret : Heap and Hammond, 1974 ; spotted skunk : Mead, 1981 ; European badger : Canivenc and Bonnin, 1979, 1981 ; stone marten : Bonnin, Canivenc and Aitken, 1977 ; striped skunk: Wade-Smith et al., 1980 ; mink: Møller, 1973b ; Allais and Martinet, 1978).

The presence of an embryo in the uterus of carnivores, species with endotheliochorial placentation, does not profoundly change luteal progesterone 
secretion. In parallel, luteal activity lasts a remarkably long time during pseudopregnancy and the uterus does not intervene to limit it.

\section{Specios with epitheliochorial placentation.}

Among studied mammals, this type of placenta characterizes artiodactyls (ewe, cow, sow, mare). The presence of an embryo in the uterus in these species prolongs the life-span of the corpus luteum; hysterectomy also extends its activity, often for as long as pregnancy.

The simplest hypothesis would be that the embryo acts by inhibiting uterine synthesis of $\mathrm{PGF}_{2 \alpha}$. However, it is not sufficient. Certainly, in the case of pregnancy, the large $\mathrm{PGF}_{2 \alpha}$ surges that follow functional luteolysis do not occur (ewe : Thorburn et al., 1973 ; Peterson et al., 1976 ; cow : Peterson et al., 1975 ; Kindahl et al., 1976a ; sow : Gleeson, Thorburn and Cox, 1974 ; Moeljono et al., 1977 ; Shille et al., 1979). But the intensity of endometrial prostaglandin synthesis that reaches a maximum at the end of the oestrous cycle is not inhibited, on the contrary it increases lewe : Husling, Fogwell and Smith, 1979 ; Ellinwood, Nett and Niswender, 1979 ; Marcus, 1981 ; Lacroix and Kann, 1982 ; cow : Lewis et al., 1982 ; sow : Guthrie and Rexroad, 1981 ; mare : Vernon et al., 1981), and the product synthesized is mainly PGE (ewe : Ellinwood, Nett and Niswender, 1979 ; Lacroix and Kann, 1982). However, we have seen (fig. 3) that PGE's can inhibit the luteolytic action of $\mathrm{PGF}_{2 \alpha}$. The preferential increase in prostaglandins $\mathrm{E}$ synthesis under the influence of the embryo therefore appears to be one of the factors involved in the transformation of the cyclic corpus luteum into a gestational one.

The putative similarity between length of pregnancy and length of luteal activity after hysterectomy is accidental. The time during which the corpus luteum is maintained after hysterectomy may vary and progesterone may fluctuate also (mare : Stabenfeldt et al., 1974) (fig.1). Luteal progesterone is only necessary during one-third of pregnancy in ewe and mare lewe : Denamur and Martinet, 1955 ; mare : Holtan et al., 1979). In cow, luteal progesterone is needed practically throughout pregnancy, but its circulating level remains constant, while after hysterectomy it shows wide fluctuations (Estergreen et al., 1967 ; Pope, Gupta and Munro, 1969 ; Donaldson, Bassett and Thorburn, 1970 ; Schams et al., 1972 ; Lindell, Edqvist and Gustafsson, 1981). The suppression of uterine $\mathrm{PGF}_{2 \alpha}$ is therefore not enough to reproduce the conditions of pregnancy.

In spite of this, the important role of the uterus in regulating the length of the oestrous cycle in these species corresponds to direct action of the embryo on the uterus with the result that progesterone secretion is maintained.

An original technique, intrauterine infusion of embryonic homogenates, has been used to show the active role of the embryo and the nature of its intervention. The infusion of embryonic homogenates (embryonic disk + trophoblast) in the uterus of cow and ewe (from day 15 in cow and from day 12 in ewe) causes a delay in the reappearance of oestrus with maintenance of progesterone secretion (Rowson and Moor, 1967 ; Martal et al., 1979 ; Northey and French, 1980). The infusion of embryonic homogenates in an empty horn of sow permits unilateral pregnancies (otherwise impossible in sow) to be maintained (Longenecker and Day, 1972 ; Ball and Day, 1982). 
In ewe, trophoblastin, an embryonic protein, seems to be mainly responsible for the transformation of uterine activity (Martal et al., 1979). In sow, oestrogens synthesized by the embryo are mainly involved (Heap, Flint and Gadsby, 1981 ; Ball and Day, 1982). After oestrogen treatment, luteal activity is also extended and is associated with a decrease in the amounts of circulating PGF $_{2 \alpha}$ (Frank et al., 1977, 1978).

Embryonic modification of uterine activity is confirmed by the effects of removing the embryo on progesterone secretion and length of the cycle. If the embryos are removed shortly before the normal period of functional luteolysis (D13 in ewe, D17 in cow, D15-16 in mare and sow), the oestrous cycle is prolonged by 5-7 days and progesterone secretion is maintained (Moor and Rowson, 1966 ; French and Strauss, 1976 ; Hershman and Douglas, 1979 ; Northey and French, 1980).

The direct action of the embryo on the uterus, fundamental to an understanding of luteal maintenance of progesterone secretion, seems to be completed by embryonic production of luteotropic LH-like or prolactin-like factors.

In cow, an LH-like protein is produced by the embryo at 18 days. In vitro, it increases the production of progesterone by luteal cells (Beal, Lukaszewska and Hansel, 1981). The placental lactogenic hormone is detected at D17 (Flint, Henville and Christie, 1979).

In ewe and sow, a protein binding to the $\mathrm{LH}$ receptors of the corpus luteum in the same species has been demonstrated in the trophoblast from D15-16 and in the placenta up to parturition (Lacroix and Martal, 1979 ; Saunders, Ziecik and Flint, 1980). Placental lactogenic hormone is produced from D16 in ewe (Martal and Djiane, 1977).

It has been known for a long time that mare produces large amounts of PMSG, a chorionic gonadotropin, between days 38-40 and 100-140 of pregnancy (see Allen, 1975).

The role of these proteins, which are known or supposed to have luteotropic activity, does not seem to be essential for maintaining luteal progesterone secretion, as demonstrated by observations in mare. The removal of the embryo at D24 (before the onset of PMSG production) is followed by " pseudopregnancy " which lasts more than a month (Kooistra and Ginther, 1976). The level of circulating progesterone is comparable after hysterectomy and, in case of pregnancy, up to the time PMSG appears. The progesterone level then increases in parallel to the increase in PMSG secretion that acts on the already formed corpus luteum and also on the follicles, causing the formation of secondary corpora lutea (Squires and Ginther, 1975 ; Nett and Pickett, 1979). The late involvement of chorionic gonadotropin in the maintenance of ovarian progesterone secretion is also of little importance in maintaining pregnancy because from D50-70, the foetoplacental unit supplies enough progesterone so that, while ovariectomy always results in a considerable drop in circulating progesterone, it no longer necessarily causes abortion (Holtan et al., 1979).

In species with epitheliochorial placentation, luteal progesterone secretion is maintained mainly by direct action of the embryo on the uterus, favoring the synthesis of luteotropic PGE's ; this is reinforced by direct action on the corpus 
luteum which the embryo supplies with luteotropic factors having LH-like and prolactin-like activity. However, the role of the placental lactogenic hormone in the maintenance of luteal progesterone secretion has never been demonstrated.

\section{Species with hemochorial placentation.}

Among studied species, rodents (rat, mouse, hamster, guinea-pig), lagomorphs (rabbit) and primates (macaque, woman) are characterized by this type of placenta. In all these mammals, the presence of an embryo in the uterus prolongs and increases luteal progesterone secretion, but often for a short time, either because pregnancy is of short duration (rat, mouse, hamster, fig. 5) or because luteal progesterone secretion is necessary only for a short time during pregnancy (guinea-pig, macaque, woman, fig. 6).

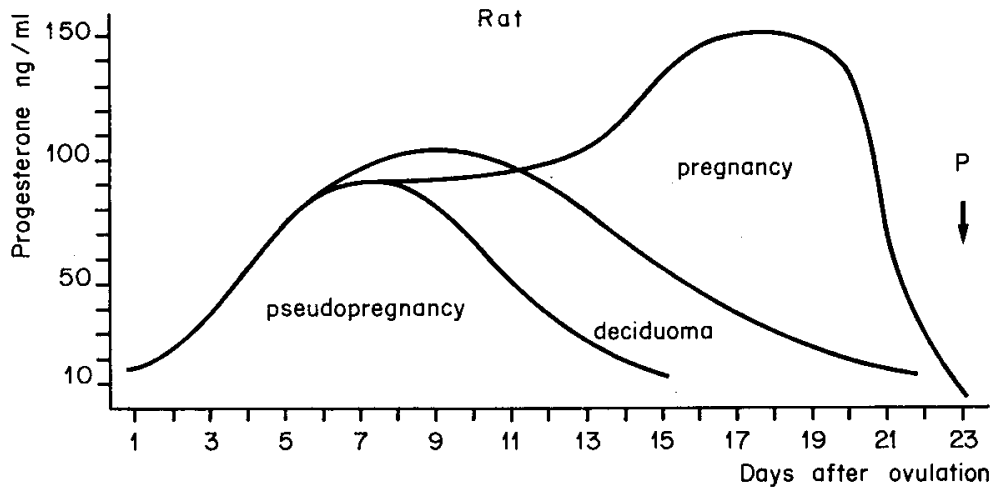

FIG. 5. - Secretion of progesterone by rat corpus luteum. Diagram showing changes in progesterone secretion in rat after sterile mating and during pregnancy. Induction of the decidual reaction in the uterus during pseudopregnancy prolongs the activity of corpus luteum by slowing down the drop in progesterone secretion. The last third of pregnancy is characterized by a considerable increase in luteal progesterone secretion.

$\mathrm{P}=$ parturition .

The uterus in all these mammals, except guinea-pig, plays a modest or inexistent role in functional luteolysis at the end of the cycle. (Moreover, the guinea-pig is the only mammal known in which hysterectomy is followed by a quantitative increase in progesterone secretion.) But these species are the ones in which the presence of the embryo in the uterus induces the most extensive anatomical changes.

Implantation, during which the embryo destroys or crosses the uterine epithelium, is preceded and accompanied by the transformation of stromal cells into decidual cells (large cells containing high amounts of glycogen and lipid). Prostaglandins are involved in the decidual reaction of the uterus and implantation. The presence of decidual tissue does not inhibit the intensity of uterine prostaglandin synthesis, on the contrary. However, it favors synthesis of PGE's rather than of $\mathrm{PGF}_{2 \alpha}$ (rat : Weems et al., 1975 ; Anteby et al., 1975 ; Castracane and Shaikh, 1976 ; Weems, 1979 ; mouse : Jonsson et al., 1979 ; Rankin et al., 1979). The inhibitors of prostaglandin synthesis prevent the decidual reaction from occurring and block implantation (mouse : Saksena, Lau and Chang, 1976 ; 

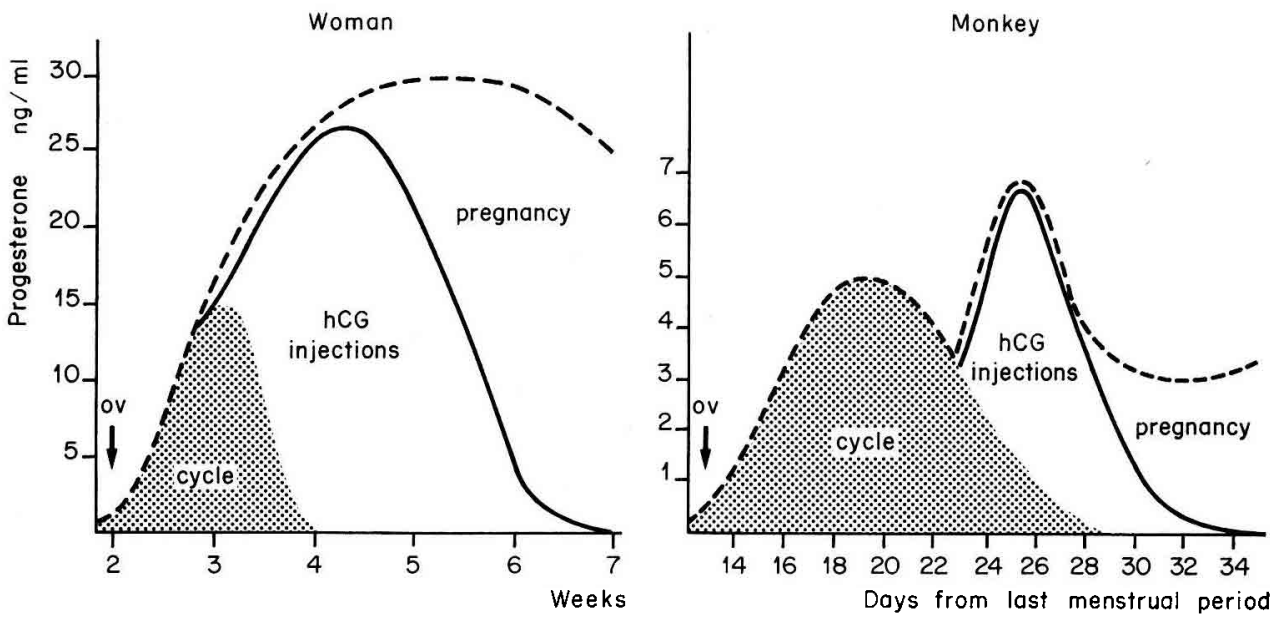

FIG. 6. - Secretion of progesterone by corpus luteum in woman and macaque. Diagram showing changes in circulating progesterone in woman and macaque during the menstrual cycle, after stimulation of corpus luteum by hCG injection and at onset of pregnancy. The rapid participation of the foetoplacental unit in progesterone production explains the high levels of progesterone observed during pregnancy when the corpus luteum, even if stimulated by chorionic hormone, no longer secretes progesterone.

Jonsson et al., 1979 ; Rankin et al., 1979 ; Holmes and Gordashko, 1980 ; Biggers, Baskar and Torchiana, 1981 ; rat : Sananes, Baulieu and Le Goascogne, 1976, 1981 ; Kennedy, 1977 ; Phillips and Poyser, 1981 ; rabbit : Hoffman, 1978 ; El-Banna, 1980). Inversely, intrauterine infusion of prostaglandins $\left(\mathrm{PGF}_{2 \alpha}, \mathrm{PGE}_{1}\right.$ or $E_{2}$ ) induces the decidual reaction (mouse : Holmes and Gordashko, 1980 ; rat : Sananes, Baulieu and Le Goascogne, 1976, 1981 ; Miller and O'Morchoe, 1982 : rabbit : Hoffman et al., 1977).

The presence of decidual tissue in the uterus (which can be experimentally induced without the presence of the embryo) often prolongs the length of pseudopregnancy by maintaining luteal phase progesterone secretion. This is the case in rat, rabbit and, to a lesser degree, hamster (rat : Gibori et al., 1974 ; Rothchild and Gibori, 1975 ; rabbit : Hoffman, Davies and Davenport, 1973 ; hamster: Terranova, 1975). PGE's might be involved because chronic $\mathrm{PGE}_{1}$ treatment slightly extends the length of pseudopregnancy (rat : Weems et al., 1979). On the contrary, in mouse and guinea-pig, the presence of decidual tissue has no apparent effect on cycle length or pseudopregnancy (mouse : De Feo, 1967 ; guinea-pig : Mitchell and Garris, 1978). In woman, decidualization in the uterus begins spontaneously during the luteal phase of the menstrual cycle. Thus, in itself, the modification of prostaglandin synthesis, resulting from the presence of decidual tissue, has little effect on luteal activity and can be compared with the minimal role of the uterus in regulating progesterone secretion ; the guinea-pig is an exception.

It is interesting to note that implantation in woman occurs at the time when uterine synthesis of prostaglandins is most intense, that is when the first signs of the decidual reaction are observed during the cycle (Noyes, Hertig and Rock, 1950 ; Downie, Poyser and Wunderlich, 1974 ; Demers et al., 1975 ; Maathuis, 
1978 ; Maathuis and Kelly, 1978). The same relationship between implantation time and maximal uterine synthesis of prostaglandins is also found in macaque (Demers, Yoshinaga and Greep, 1974).

When the uterus plays a role in the regulation of progesterone secretion, maximal uterine synthesis of prostaglandins is obviously observed at the end of the cycle or of pseudopregnancy. However, this synthesis is intensified at the time of implantation (guinea-pig : Poyser, 1972 ; Blatchley et al., 1972 ; hamster : Shaikh, Birchall and Saksena, 1973). This variation in uterine synthesis of prostaglandins could be involved in the fact that there is a period when the uterus is sensitive to experimental induction of the decidual reaction (see De Feo, 1967).

The maintenance of luteal progesterone secretion, and especially the increase in that secretion by the gestational corpus luteum, is always related to embryonic production of an $\mathrm{LH}$-like chorionic gonadotropin. This hormone, detected in maternal circulating blood from the time of implantation in woman and macaque (Saxena et al., 1974 ; Hodgen et al., 1974), is then produced in large quantities. The injection of this hormone ( $\mathrm{hCG}$ or $\mathrm{mCG}$ ) increases and extends luteal progesterone secretion as at the onset of pregnancy (macaque : Neill and Knobil, 1972 ; Bosu and Johansson, 1974 ; woman : Tu, 1978 ; Quagliarello et al., 1980). In woman as in macaque, continuous hCG treatment does not prevent luteolysis from finally intervening but at the same time, in the case of pregnancy, progesterone is supplied by the foetoplacental unit, ovariectomy or lutectomy no longer causing abortion (Csapo et al., 1972, 1973 ; Berg, Thor and Johansson, 1975 ; Goodman and Hodgen, 1979). An LH-like chorionic gonadotropin has also been demonstrated in the placenta of mouse, rat, hamster and guinea-pig at implantation time or shortly thereafter. It is present throughout pregnancy (rat : Haour, Tell and Sanchez, 1976 ; Bambra and Gombe, 1978 ; Blank, Dufau and Friesen, 1979 ; mouse : Wide and Wide, 1979 ; Rao, Pointis and Cedard, 1982 ; hamster : Wide and Hobson, 1978 ; guinea-pig : Humphreys, Hobson and Wide, 1982). In rabbit, embryonic production of an LH-like chorionic gonadotropin has been observed even before implantation ; unfortunately, nothing is known about its existence during pregnancy (Haour and Saxena, 1974 ; Fujimoto et al., 1975 ; Asch et al., 1979).

This chorionic hormone certainly plays an important role in progesterone secretion by gestational corpus luteum. Alone, however, it probably does not have such a role as in woman and macaque. In woman, LH treatment as hCG treatment permits the increase and prolongation of luteal progesterone secretion (Hanson, Powell and Stevens, 1971). In rat, LH implants in the ovary only prolong pseudopregnancy by several days, while the corpus luteum is responsible for the circulating progesterone level throughout pregnancy, even though the foetoplacental units produces a little progesterone at the end of pregnancy (Liao, Pattison and Chen, 1974 ; Legrand et al., 1979).

Luteal progesterone secretion always depends on two hormones, one LH or LH-like and the other prolactin or prolactin-like, In woman, decidual cells secrete prolactin (Maslar and Riddick, 1979 ; Kubota et al., 1981). In rat, they secrete a "prolactin-like » protein that binds to the prolactin receptors of the corpus luteum (Gibori et al., 1974 ; Basuray and Gibori, 1980). 
The existence of a uterine prolactin has not been demonstrated in other species. However, it may be surmised. In fact, bromocryptine, a dopamine agonist, acts on the pituitary, inhibiting prolactin secretion, but it has no effect on decidual cell prolactin secretion (woman : Schulz et al., 1978). In mouse, hamster and rat, bromocryptine treatment of pregnant females causes a decline in progesterone levels and abortion until the decidual tissue is established. It then has no effect (Ford and Yoshinaga, 1975; Mednick, Barley and Geschwind, 1980 ; Tabarelli et al., 1982). It is thus probable that the decidual cells produce a prolactin-like protein $\left(^{*}\right)$ (see p. 816 ).

A placental lactogenic hormone of embryonic origin, that could take over from prolactin, is produced later (rat: Kelly et al., 1975 ; Blank, Dufau and Friesen, 1979 ; Tabarelli et al., 1982 ; mouse : Soares, Colosi and Talamantes, 1982). Moreover, the placental lactogenic hormone has no luteotropic effect on the corpus luteum in woman because it is only secreted when the corpus luteum has stopped producing the progesterone necessary for pregnancy (Friesen, Suwa and Pare, 1969).

The production of a chorionic gonadotropin with LH activity, and thus of embryonic origin, associated with uterine production of prolactin, would permit the secretion of progesterone by the corpus luteum that is characteristic of pregnancy. Placental lactogenic hormone might also be involved.

The role of uterine PGE's in the maintenance of progesterone secretion appears to vary with the case. It is probably not negligeable in rabbit and rat ; in rabbit, very high amounts of $\mathrm{PGE}_{2}$ are produced by the uterus during the last twothirds of pregnancy (Lytton and Poyser, 1982). In rat, PGE's are abundantly produced when the uterus is decidualized, especially if an embryo is present during at least the first half of pregnancy (Anteby et al., 1975). However, $\mathrm{LH}$-prolactin association is no more effective than $\mathrm{LH}$ alone in prolonging the length of pseudopregnancy (Liao, Pattison and Chen, 1974). It may thus be that decidual tissue acts by producing both a " prolactin-like " hormone and PGE. On the other hand, in guinea-pig and woman, the onset of pregnancy is characterized by a decrease in PGE production (woman : Maathuis and Kelly, 1978 ; guineapig : Antonini, Turner and Pauerstein, 1976 ; Poyser and Maule-Walker, 1979). This particularity could be related to the interstitial implantation characterizing these two species (the embryo penetrates the uterine tissue very quickly, practically without destroying the epithelium).

In mammals with hemochorial placentation, the association of embryonic production of an LH-like chorionic gonadotropin and decidual tissue production of a uterine " prolactin " may account for secretion of progesterone by gestational corpus luteum. Changes in the synthesis of uterine prostaglandins may also play a role of variable importance comparable to that of the uterus in the regulation of luteal function in these species.

\section{Conclusion.}

According to the nature of the relationship established between mother and embryo - epitheliochorial, endotheliochorial or hemochorial placentation - the 
role of the embryo in the regulation of luteal progesterone secretion appears to be quite similar, having :

- no apparent role in species with endotheliochorial placentation,

- a large role but with somewhat different means in species with epitheliochorial placentation and hemochorial placentation. In both cases, the embryo produces an LH-like chorionic gonadotropin. In both cases, the embryo transforms uterine activity, mainly favoring PGE synthesis in species with epitheliochorial placentation and mainly inducing decidualization of the uterus, and thus the synthesis of a uterine prolactin, in species with hemochorial placentation.

In these three groups, the role of the uterus in regulating the secretion of progesterone by the cyclic corpus luteum also presents analogies, but some unexplained exceptions are found in species with hemochorial placentation, such as guinea-pig.

Many other differences exist in the regulation of ovarian function and uterine activity. Insofar as they are not related to placental type, they should provide an answer as to the causes of observed differences and their significance.

Reçu en novembre 1982. Accepté en mars 1983.

Acknowledgements. - The author wishes to thank Ms. A. Daifuku for the English translation, Miss S. Ruffini for typing the paper and Mr. J. Gallé for the drawing.

Résumé. Les relations utéro-ovariennes chez les mammifères placentaires. Rôle de l'utérus et de l'embryon dans la régulation de la sécrétion de progestérone par le corps jaune.

Le rôle de l'utérus et le rôle de l'embryon dans la régulation de la sécrétion de progestérone par le corps jaune apparaissent très différents selon les mammifères. II existe cependant des analogies de situation entre certains d'entre eux. Le rôle essentiel de la progestérone lutéale est de permettre l'établissement et le maintien de la gestation et une relation nous est apparue entre le type de placenta et le mode de régulation de l'activité lutéale par l'utérus et l'embryon.

Quand la placentation est endothéliochoriale (carnivores) la durée d'activité du corps jaune est remarquablement longue ; chez aucune des espèces étudiées l'utérus n'intervient pour la limiter et la présence d'un embryon ne semble pas modifier profondément la sécrétion de progestérone par le corps jaune.

Quand la placentation est épithéliochoriale (artiodactyles), pour toutes les espèces étudiées l'hystérectomie comme la présence d'un embryon dans l'utérus entraînent un prolongement important de l'activité du corps jaune. L'utérus limite la durée de la sécrétion de progestérone par une production de $\mathrm{PGF}_{2 \alpha}$ lutéolytique. L'embryon provoque son maintien par une action directe sur l'utérus dont la conséquence est une modification de la synthèse de prostaglandines qui privilégie éventuellement celle des PGE lutéotropes. En outre, l'embryon sécrète des facteurs lutéotropes à activité $\mathrm{LH}$ et peut-être prolactine.

Quand la placentation est hémochoriale (rongeurs, lagomorphes, primates supérieurs) pour toutes les espèces étudiées (à l'exception du cobaye) l'utérus joue un rôle modeste ou nul dans la régulation de l'activité du corps jaune. La présence d'un embryon prolonge et souvent augmente la production de progestérone. L'embryon agit de deux manières : en provoquant dans l'endomètre la formation du tissu décidual producteur de facteurs lutéotropes, " prolactine " utérine et parfois PGE, et en sécrétant une hormone chorionique à activité $\mathrm{LH}$ dont la production est quantitativement très importante chez les primates. 


\section{References}

ALLAIS C., MARTINET L., 1978. Relation between daylight ratio, plasma progesterone levels and timing of nidation in mink (Mustela vison). J. Reprod. Fert., 54, 133-136.

ALLEN W. R., 1975. The influence of fetal genotype upon endometrial cup development and PMSG and progestogen production in equids. J. Reprod. Fert., Suppl. 23, 405-413.

ALVAREZ-SANCHEZ F., SEGAL S. J., BRACHE V., ADEJUWON C. A., LEON P., FAUNDES A., 1981. Pituitary-ovarian function after tubal ligation. Fertil. Steril., 36, 606-609.

ALWACHI S. N., BLAND K. P., POYSER N. L., 1981. Additional pathway of transfer of uterine prostaglandin $F_{2 \alpha}$ to the ovary in sheep. J. Reprod. Fert., 61, 197-200.

ANDERSON L. L., BLAND K. P., MELAMPY R. M., 1969. Comparative aspects of uterine-luteal relationship. Rec. Progr. Horm. Res., 25, 57-104.

ANTEBY S. O., BAUMINGER S., ZOR U., LINDNER H. R., 1975. Prostaglandin synthesis in decidual tissue of the rat uterus. Prostaglandins, 10, 991-999.

ANTONINI R., TURNER T. T., PAUERSTEIN C. J., 1976. The hormonal control of the guinea pig corpus luteum during early pregnancy. Fertil. Steril., 27, 1322-1325.

ASCH R. H., FERNANDEZ E. O., SILER-KHODR T. M., PAUERSTEIN C. J., 1979. Evidence for a human chorionic gonadotropin-like material in the rabbit blastocyst. Fertil. Steril., 32, 697703.

AULETTA F. J., AGINS H., SCOMMEGNA A., 1978. Prostaglandin F mediation of the inhibitory effect of estrogen on the corpus luteum of the rhesus monkey. Endocrinology, 103, 1183 1189.

BAIRD D. T., LAND R. B., 1973. Division of the uterine vein and the function of the adjacent ovary in the ewe. J. Reprod. Fert., 33, 393-397.

BAKER B. A., ARCHBALD L. F., CLOONEY L. L., LOTZ K., GODKE R. A., 1980. Luteal function in the hysterectomized bitch following treatment with prostaglandin $F_{2 \alpha}\left(\mathrm{PGF}_{2 \alpha}\right)$. Theriogenology, 14, 195-205.

BALL G. D., DAY B. N., 1982. Bilateral luteal maintenance in unilaterally pregnant pigs with infusions of embryonic extracts. J. anim. Sci, 54, 142-149.

BAMBRA C. S., GOMBE S., 1978. The role of placental gonadotrophins (PMSG and hCG) in pregnancy in the rat. $J$. Reprod. Fert., 53, 109-115.

BASURAY R., GIBORI G., 1980. Luteotropic action of decidual tissue in the pregnant rat. Biol. Reprod., 23, 507-512.

BEAL W. E., LUKASZEWSKA J. H., HANSEL W., 1981. Luteotropic effects of bovine blastocysts. J. anim. Sci., 52, 567-574.

BENDZ A., 1977. The anatomical basis for a possible counter current exchange mechanism in the human adnex. Prostaglandins, 13, 355-362.

BENDZ A., 1982. Counter current exchange in the human female reproductive tract. Ph. D. Thesis Göteborg.

BENZ A., EINER-JENSEN N., LUNDGREN O., JANSON P. O., 1979. Exchange of krypton-85 between the blood vessels of the human uterine adnexa. J. Reprod. Fert., 57, 137-142.

BERG A. A., THOR L., JOHANSSON E. D. B., 1975. Luteectomy in early pregnancy. Ann. Chir. Gynec. Fenn., 64, 249-251.

BIGGERS J. D., BASKAR J. F., TORCHIANA D. F., 1981. Reduction of fertility of mice by the intrauterine injection of prostaglandin antagonists. J. Reprod. Fert., 63, 365-372.

BLAND K. P., DONOVAN B. T., 1969. Observations on the time of action and the pathway of the uterine luteolytic effect of the guinea pig. J. Endocr., 43, 259-264.

BLANK M. S., DUFAU M., FRIESEN H. G., 1979. Demonstration of potent, gonadotropin-like biological activity in the serum of rats during midpregnancy. Life Sci., 25, 1023-1028.

BLATCHLEY F. R., DONOVAN B. T., HORTON E. W., POYSER N. L., 1972. The release of prostaglandins and progestin into the utero-ovarian venous blood of guinea pigs during the oestrous cycle and following oestrogen treatment. J. Physiol., 223, 69-88.

BONNEY R. C., MOORE H. D. M., JONES D. M., 1981. Plasma concentrations of oestradiol-17 $\beta$ and progesterone, and laparoscopic observations of the ovary in the puma (Felis concolor) during oestrus, pseudopregnancy and pregnancy. J. Reprod. Fert., 63, 523-531. 
BONNIN M., CANIVENC R., AITKEN J., 1977. Variations saisonnières du taux de progestérone plasmatique chez la fouine Martes foina, espèce à ovo-implantation différée. C. R. Acad. Sci., Paris, Sér. D, 285, 1479-1481.

BONNIN M., CANIVENC R., CHARRON G., 1981. Variations du taux de la progestérone plasmatique chez la femelle de blaireau après ablation de l'utérus gravide. C. R. Acad. Sci., Paris, Sér. $D, 293,143-145$.

BONNIN M., MONDAIN-MONVAL M., DUTOURNÉ B., 1978. Oestrogen and progesterone concentrations in peripheral blood in pregnant red foxes (Vulpes vulpes). J. Reprod. Fert., 54, 37-41.

BOSU W. T. K., JOHANSSON E. D. B., 1974. Effect of hCG on plasma levels of estrogens and progesterone during the luteal phase of the menstrual cycle in rhesus monkeys (Macaca mulatta). Int. J. Fertil., 19, 28-32.

BROWNING J. Y., WOLF R. C., 1981. Maternal recognition of pregnancy in the rabbit : effect of conceptus removal. Biol. Reprod., 24, 293-297.

CANIVENC R., BONNIN M., 1979. Delayed implantation is under environmental control in the badger (Meles meles). Nature, 278, 849-850.

CANIVENC R., BONNIN M., 1981. Environmental control of delayed implantation in the European badger (Meles meles). J. Reprod. Fert., suppl. 29, 25-33.

CANIVENC R., BONNIN-LAFARGUE M., LAJUS M., 1966. L'utérus gravide a-t-il une fonction lutéotrope chez le vison (Mustela vison). C. R. Soc. Biol., 160, 2285-2287.

CANIVENC R., BONNIN-LAFARGUE M., RELEXANS M. C., 1962. L'utérus gravide a-t-il une fonction lutéotrope chez le blaireau européen (Meles meles) ? C. R. Soc. Biol., 156, 13721375.

CARLSON I. H., RUST C. C., 1969. Plasma progesterone levels in pregnant, pseudopregnant and anestrous ferrets. Endocrinology, 85, 623-624.

CASTRACANE V. D., MOORE G. T., SHAIKH A. A., 1979, Ovarian function in hysterectomized Macaca fascicularis. Biol. Reprod., 20, 462-472.

CASTRACANE V. D., SHAIKH A. A., 1976. Effect of decidual tissue on the uterine production of prostaglandins in pseudopregnant rats. J. Reprod. Fert., 46. 101-104.

CHALLIS J. R. G., FORSTER C. S., FURR B. J. A., ROBINSON J. S., THORBURN G.D., 1976. Production of prostaglandin $F_{2 \alpha}$ in ewes following luteal regression induced with a prostaglandin analogue, estrumate (cloprostenol ; ICl 80996). Prostaglandins, 11, 537-543.

CLEMENS J. A., MINAGUCHi H., MEITES J., 1968. Relation of local circulation between ovaries and uterus to lifespan of corpora lutea in rats. Proc. Soc. exp. Biol. Med., 127, 1248-1251.

CONCANNON P., 1980. Effects of hypophysectomy and of LH administration on luteal phase plasma progesterone levels in the beagle bitch. J. Reprod. Fert., 58, 407-410.

CONCANNON P., 1981. In ROTCHCHILD I., The regulation of the mammalian corpus luteum. Rec. Progr. Horm. Res., 37, 287-290.

CONCANNON P. W., HANSEL W., VISEK W. J., 1975. The ovarian cycle of the bitch : plasma estrogen, $\mathrm{LH}$ and progesterone. Biol. Reprod, 13, 112-121.

CRISTER E. S., RUTLEDGE J. J., FRENCH L. R., 1981. Effect of indomethacin on the interestrous interval of intact and hysterectomized pseudopregnant mice. Biol. Reprod., 24, 1000-1005.

CSAPO A. I., PULKKINEN M. O., RUTTNER B., SAUVAGE J. P., WIEST W. G., 1972. The significance of the human corpus luteum in pregnancy maintenance. I. Preliminary studies. Am. J. Obst. Gynec., 112, 1061-1067.

CSAPO A. I., PULKKINEN M. O., WIEST W. G., 1973. Effects of luteectomy and progesterone replacement therapy in early pregnant patients. Am. J. Obst. Gynec., 115, 759-765.

DEANESLY R., PARKES A. S., 1933. The effect of hysterectomy on the oestrous cycle of the ferret. J. Physiol., 78, 80-85.

DE FEO V. J., 1967. Decidualization, 191-290. In WYNN R. M., Cellular biology of the uterus. North-Holland Publ. Co., Amsterdam.

De GREEF W. J., DULLAART J., ZEILMAKER G. H., 1976. Effect of hysterectomy on serum luteinizing hormone concentrations and on corpus luteum function in the rat. Endocrinology, 98, 1228-1234. 
DEL CAMPO C. H., GINTHER O. J., 1972. Vascular anatomy of the uterus and ovaries and the unilateral luteolytic effect of the uterus : guinea pigs, rats, hamsters and rabbits. Am. J. Vet. Res., 33, 2561-2578.

DEL CAMPO C. H., GINTHER O. J., 1973. Vascular anatomy of the uterus and ovaries and the unilateral luteolytic effect of the uterus : horses, sheep and swine. Am. J. Vet. Res., 34, 305316.

DEL CAMPO C. H., GINTHER O. J., 1974. Arteries and veins of uterus and ovaries in dogs and cats. Am. J. vet. Res., 35, 409-415.

DEMERS L. M., HALBERT D. R., JONES D. E. D., FONTANA J., 1975. Prostaglandin F levels in endometrial jet wash specimens during the normal human menstrual cycle. Prostaglandins, 10, 1057-1065.

DEMERS L. M., YOSHINAGA K., GREEP R. O., 1974. Prostaglandin F in monkey uterine fluid during the menstrual cycle and following steroid treatment. Prostaglandins, 5, 513-519.

DENAMUR R., MARTINET J., 1955. Effets de l'ovariectomie chez la brebis pendant la gestation. C. R. Soc. Biol., 149, 2105-2107.

DOBROWOLKSI W., HAFEZ E. S. E., 1970. The effect of destruction of utero-ovarian vascular connections on the lifespan of the corpus luteum in sheep. J. Reprod. Fert., 23, 165-167.

DONALDSON L. E., BASSETT J. M., THORBURN G. D., 1970. Peripheral plasma progesterone concentration of cows during puberty, oestrous cycles, pregnancy and lactation, and the effects of undernutrition or exogenous oxytocin on progesterone concentration. J. Endocr., 48, 599-614.

DOWNIE J., POYSER N. L., WUNDERLICH M., 1974. Levels of prostaglandins in human endometrium during the normal menstrual cycle. J. Physiol., 235, 465-472.

DOYLE L. L., BARCLAY D. L., DUNCAN G. W., KIRTON K. T., 1971. Human luteal function following hysterectomy as assessed by plasma progestin. Am. J. Obst. Gynec., 110. 92-97.

DUBY R. T., 1972. The influence of melatonin and hysterectomy on plasma progesterone levels of the mink (Mustela vison), (abstr.). Biol. Reprod., 7, 125.

DUBY R. T., McDANIEL J. W., SPILMAN C. H., BLACK D. L., 1969.' Utero-ovarian relationships in the golden hamster. Acta endocr., 60, 595-602.

EL-BANNA A. A., 1980. The degenerative effect on rabbit implantation sites by indomethacin. I. Timing of indomethacin action, possible effect on uterine proteins and the effect of replacement doses of $\mathrm{PGF}_{2 \alpha}$. Prostaglandins, 20, 587-599.

ELLINWOOD W. E., NETT T. M., NISWENDER G. D., 1979. Maintenance of the corpus luteum of early pregnancy in the ewe. II. Prostaglandin secretion by the endometrium in vitro and in vivo. Biol. Reprod., 21, 845-856.

ESTERGREEN V. L., FROST O. L., GOMES W. R., ERB R. E., BULLARD J. F., 1967. Effect of ovariectomy on pregnancy maintenance and parturition in dairy cows. J. Dairy Sci, 50 , 1293-1295.

FISCHER T. V., 1971. Local pathway controlling luteal function in the guinea pig. Biol. Reprod., 4, 126-128.

FLINT A. P. F., HENVILLE A., CHRISTIE W. B., 1979. Presence of placental lactogen in bovine conceptuses before attachment. J. Reprod. Fert., 56, 305-308.

FORD J. J., YOSHINAGA K., 1975. Ergocryptine and pregnancy maintenance in hamsters. Proc. Soc. exp. Biol., Med., 150, 425-427.

FRANK M., BAZER F. W., THATCHER W. W., WILCOX C. J., 1977. A study of prostaglandin $\mathrm{F}_{2 \alpha}$ as the luteolysin in swine : effects of estradiol valerate on prostaglandin $F$, progestins, estrone and estradiol concentrations in the utero-ovarian vein of non pregnant gilts. Prostaglandins, 14, 1183-1196.

FRANK M., BAZER F. W., THATCHER W. W., WILCOX C. J., 1978. A study of prostaglandin $F_{2 \alpha}$ as the luteolysin in swine : an explanation for the luteotrophic effect of estradiol. Prostaglandins, 15, 151-160.

FRASER I. S., BAIRD D. T., HOBSON B. M., MICHIE E. A., HUNTER W., 1973. Cyclical ovarian function in women with congenital absence of the uterus and vagina. J. clin. Endocr. Metab., 36, 634-637.

FRENCH L. R., STRAUSS W., 1976. Embryo removal and interestrous intervals in pigs. J. anim. Sci., 43, 285 (abstr.). 
FRIESEN H. G., SUWA S., PARE P., 1969. Synthesis and secretion of placental lactogen and other proteins by the placenta. Rec. Progr. Horm. Res., 25, 161-205.

FUJIMOTO S., EUKER J. S., RIEGLE G. D., DUKELOW W. R., 1975. On a substance crossreacting with luteinizing hormone in the pre-implantation blastocyst fluid of the rabbit. Proc. japan Acad., 51, 123-125.

GERBER J. G., HUBBARD W. C., NIES A. S., 1979. Uterine vein prostaglandin levels in late pregnant dogs. Prostaglandins, 17, 623-627.

GIBORI G., ROTHCHILD I., PEPE G. J., MORISHIGE W. K., LAM P., 1974. Luteotrophic action of decidual tissue in the rat. Endocrinology, 95, 1113-1118.

GINTHER O. J., DIERSCHKE D. J., WALSH S. W., DEL CAMPO C. H., 1974. Anatomy of arteries and veins of uterus and ovaries in rhesus monkeys. Biol. Reprod., 11, 205-219.

GLEESON A. R., THORBURN G. D., COX R. I., 1974. Prostaglandin F concentrations in the uteroovarian venous plasma of the sow during the late luteal phase of the oestrous cycle. Prostaglandins, 5, 521-529.

GOODMAN A. L., HODGEN G. D., 1979. Corpus luteum-conceptus-follicle relationships during the fertile cycle in rhesus monkeys : pregnancy maintenance despite early luteal removal. $J$. clin. Endocr. Metab., 49, 469-471.

GROS G., 1936. Le cycle génital de la chatte. Th. Méd., Alger.

GUTHRIE H. D., REXROAD C. E., 1981. Endometrial prostaglandin F release in vitro and plasma 13,14-dihydro-15-ketoprostaglandin $F_{2 \alpha}$ in pigs with luteolysis blocked by pregnancy, estradiol benzoate or human chorionic gonadotropin. J. anim. Sci., 52, 330-339.

HADLEY J. C., 1975a. Total unconjugated oestrogen and progesterone concentrations in peripheral blood during the oestrous cycle of the dog. J. Reprod. Fert., 44, 445-451.

HADLEY J. C., 1975b. The effect of serial uterine biopsies and hysterectomy on peripheral blood levels of total unconjugated oestrogen and progesterone in the bitch. J. Reprod. Fert., $\mathbf{4 5}$, 389-393.

HANSON F. W., POWELL J. E., STEVENS V. C., 1971. Effects of hCG and human pituitary LH on steroid secretion and functional life of the human corpus luteum. J. clin. Endocr. Metab., 32, 211-215.

HAOUR F., SAXENA B. B., 1974. Detection of a gonadotropin in rabbit blastocyst before implantation. Science, 185, 444-445.

HAOUR F., TELL G., SANCHEZ P., 1976. Mise en évidence et dosage d'une gonadotropine chorionique chez le rat (rCG). C. R. Acad. Sci. Paris, Sér. D, 282, 1183-1186.

HEAP R. B., FLINT A. P., GADSBY J. E., 1981. Embryonic signals and material recognition, 311-326. In GLASSER S. R., BULLOCK D. W. Cellular and molecular aspects of implantation. Plenum Press, New York.

HEAP R. B., HAMMOND J., 1974. Plasma progesterone levels in pregnant and pseudopregnant ferrets. J. Reprod. Fert., 39, 149-152.

HENDERSON K. M., SCARAMUZZI R. J., BAIRD D. T., 1977. Simultaneous infusion of prostaglandin $\mathrm{E}_{2}$ antagonizes the luteolytic action of prostaglandin $\mathrm{F}_{2 \alpha}$ in vivo. $J$. Endocr., 72 , 379-383.

HERSHMAN L., DOUGLAS R. H., 1979. The critical period for the maternal recognition of pregnancy in pony mares. J. Reprod. Fert., suppl. 27, 395-401.

HILLIARD J., SCARAMUZZI R. J., PENARDI R., SAWYER C. H., 1974. Serum progesterone levels in hysterectomized pseudopregnant rabbits. Proc. Soc. exp. Biol. Med., 145, 151-153.

HIXON J. E., HANSEL W., 1974. Evidence for preferential transfer of prostaglandin $F_{2 \alpha}$ to the ovarian artery following intrauterine administration in cattle. Biol. Reprod., 11, 543-552.

HODGEN G. D., TULLNER W. W., VAITUKAITIS J. L., WARD D. N., ROSS G. T., 1974. Specific radioimmunoassay of chorionic gonadotropin during implantation in rhesus monkeys. J. clin. Endocr. Metab., 39, 457-464.

HOFFMAN L. H., 1978. Antifertility effects of indomethacin during early pregnancy in the rabbit. Biol. Reprod., 18, 148-153.

HOFFMAN L. H., DAVIES J., DAVENPORT G. R., 1973. The effects of hysterectomy and decidual induction on luteal maintenance in rabbits. Endocrinology, 93, 348-355.

HOFFMAN L. H., STRONG G. B., DAVENPORT G. R., FRÖLICH J. C., 1977. Deciduogenic effect of prostaglandins in the pseudopregnant rabbit. J. Reprod. Fert., 50, 231-237. 
HOLMES P. V., GORDASHKO B. J., 1980. Evidence of prostaglandin involvement in blastocyst implantation. J. Embryol. exp. Morph., 55, 109-122.

HOLTAN D. W., SQUIRES E. L., LAPIN D. R., GINTHER O. J., 1979. Effect of ovariectomy on pregnancy in mares. J. Reprod. Fert., suppl. 27, 457-463.

HORTON E. W., POYSER N. L., 1973. Elongation of oestrous cycle in the guinea pig following subcutaneous or intrauterine administration of indomethacin. Brit. J. Pharmacol., 49, 98-105.

HUIE J. M., MAGNESS R. R., REYNOLDS L. P., HOYER G., HUECKSTEADT T., COLCORD M., STALCUP B., WHYSONG G. L., WEEMS C. W., 1981. Effect of chronic ipsilateral or contralateral intrauterine infusion of prostaglandin $E_{1}\left(P G E_{1}\right)$ on luteal function of unilaterally ovariectomized ewes. Prostaglandins, 21, 945-955.

HUMPHREYS E. M., HOBSON B. M., WIDE L., 1982. Gonadotrophic activity of the guinea pig placenta during pregnancy. $J$. Reprod. Fert., 65, 231-238.

HUSLING R. L., FOGWELL R. L., SMITH W. L., 1979. The prostaglandin forming cyclo oxygenase of ovine uterus : relationship to luteal function. Biol. Reprod., 21, 589-600.

INSKEEP E. K., BUTCHER R. L., 1966. Local component of utero-ovarian relationship in the ewe. J. anim. Sci., 25, 1164-1168.

JONSSON H. T., RANKIN J. C., LEDFORD B. E., BAGGETT B., 1979. Uterine prostaglandin levels following stimulation of the decidual cell reaction: effects of indomethacin and tranylcypromine. Prostaglandins, 18, 847-857.

KANN G., LACROIX M. C., 1982. Effects of systemic administration of indomethacin to cyclic ewes on endometrial concentrations of prostaglandins. Effects on estrous cycle length and on progesterone, luteinizing hormone and prolactin patterns. Prostaglandins, 23, 527-541.

KELLY P. A., SHIU R. P. C., ROBERTSON M. C., FRIESEN H. G., 1975. Characterization of rat chorionic mammotropin. Endocrinology, 96, 1187-1195.

KENNEDY T. G., 1977. Evidence for a role of prostaglandins in the initiation of blastocyst implantation in the rat. Biol. Reprod., 16, 286-291.

KINDAHL H., EDQVIST L. E., BANE A., GRANSTRÖM E., 1976a. Blood levels of progesterone and 15-keto-13, 14-dihydro-prostaglandin $F_{2 x}$ during the normal oestrous cycle and early pregnancy in heifers. Acta endocr., 82, 134-149.

KINDAHL H., GRANSTRÖM E., EDOVIST L. E., ENEROTH P., 1976b. Prostaglandin levels in peripheral plasma during the reproductive cycle. Adv. Prostaglandin Thromboxane Res., 2, 667-671.

KOOISTRA L. H., GINTHER O. J., 1976. Termination of pseudopregnancy by administration of prostaglandin $F_{2 \alpha}$ and termination of early pregnancy by administration of prostaglandin $F_{2 \alpha}$ or colchicine or by removal of embryo in mares. Am. J. vet. Res., 37, 35-39.

KOTWICA J., 1980. Mechanism of prostaglandin $F_{2 \alpha}$ penetration from the horn of the uterus to the ovaries in pigs. J. Reprod. Fert., 59, 237-241.

KOULLAPIS E. N., COLLINS W. P., 1980. The concentration of 13,14-dihydro-15-oxo-prostaglandin $\mathrm{F}_{2 \alpha}$ in peripheral venous plasma throughout the normal ovarian and menstrual cycle. Acta endocr., 93, 123-128.

KRAELING R. R., RAMPACEK G. B., KISER T. E., 1981. Corpus luteum function after indomethacin treatment during the estrous cycle and following hysterectomy in the gilt. Biol. Reprod., 25. 511-518.

KRZYMOWSKI T., KOTWICA J., STEFANCZYK S., DEBEK J., CZARNOCKI J., 1982. Steroid transfer from the ovarian vein to the ovarian artery in the sow. J. Reprod. Fert., 65, 451-456.

KRZYMOWSKI T., STEFANCZYK S., KOTWICA J., CZARNOCKI J., GLASER T., JANOWSKI T., CHMIEL J., 1981/1982. ${ }^{3} \mathrm{H}$-estradiol $17 \beta$ counter current transfer from the ovarian vein into the ovarian artery in cows. Anim. Reprod. Sci., 4, 199-206.

KUBOTA T., KUMASAKA T., YAOI Y., SUZUKI A., SAITO M., 1981. Study on immunoreactive prolactin of decidua in early pregnancy. Acta endocr., 96, 258-264.

LACROIX M. C., KANN G., 1982. Comparative studies of prostaglandins $F_{2 \alpha}$ and $E_{2}$ in late cyclic and early pregnant sheep. Prostaglandins, 23, 507-526.

LACROIX M. C., MARTAL J., 1979. Mise en évidence et évolution d'une gonadotropine chorionique chez la brebis. C. R. Acad. Sci. Paris, Sér. D, 288, 771-774.

LAMOND D. R., DROST M., 1973. The counter current transfer of prostaglandin in the ewe. Prostaglandins, 3, 691-701. 
LAU I. F., SAKSENA S. K., CHANG M. C., 1975. Effect of indomethacin, an inhibitor of prostaglandin biosynthesis on the length of pseudopregnancy in rats and hamsters. Acta endocr., 78, 343-348.

LEGRAND C., SYNGUELAKIS M., EMMERICH A., ROBEL P., 1979. Relationships among placental, uterine and circulating concentrations of progesterone and fetal survival in the ovariectomized pregnant rat. Endocrinology, 105, 58-63.

LEVITT M. J., TOBON H., JOSIMOVICH J. B., 1975. Prostaglandin content of human endometrium, Fertil. Steril., 26, 296-300.

LEWIS G. S., THATCHER W. W., BAZER F. W., CURL J. S., 1982. Metabolism of arachidonic acid in vitro by bovine blastocysts and endometrium. Biol. Reprod., 27, 431-439.

LIAO T. F., PATTISON M. L., CHEN C. L., 1974. Prolongation of pseudopregnancy of rats by gonadotropins implanted in the ovarian bursae. Endocrinology, 95, 1234-1239.

LINDELL J. O., EDQVIST L. E., GUSTAFSSON B., 1981. Oophorectomy during different stages of pregnancy in the cow. Acta vet. scand., 22, 553-565.

LONGENECKER D. E., DAY B. N., 1972. Maintenance of corpora lutea and pregnancy in unilaterally pregnant gilts by intrauterine infusion of embryonic tissue. J. Reprod. Fert., 31, 171177.

LYTTON F. D. C., POYSER N. L., 1982. Concentrations of $\mathrm{PGF}_{2 \alpha x}$ and $\mathrm{PGE}_{2}$ in the uterine venous blood of rabbits during pseudopregnancy and pregnancy. J. Reprod. Fert., 64, 421-429.

MAATHUIS J. B., 1978. Cyclic changes in the concentration of prostaglandin $F_{2 \alpha}$ in human uterine flushings. Brit. J. Obst. Gynec., 85, 207-210.

MAATHUIS J. B., KELLY R. W., 1978. Concentrations of prostaglandins $F_{2 \alpha}$ and $E_{2}$ in the endometrium throughout the human menstrual cycle, after the administration of clomiphene or an oestrogen-progestogen pill and in early pregnancy. J. Endocr., 77, 361-371.

McCRAKEN J. A., CARLSON J. C., GLEW M. E., GODING J. R., BAIRD D. T., GREEN K., SAMUELSSON B., 1972. Prostaglandin $F_{2 \alpha}$ identified as a luteolytic hormone in sheep. Nature new Biol., 238, 129-134.

MAGNESS R. R., HUIE J. M., HOYER G. L., HUECKSTEADT T. P., REYNOLDS L. P., SEPERICH G. J., WHYSONG G., WEEMS C. W., 1981. Effect of chronic ipsilateral or contralateral intrauterine infusion of prostaglandin $E_{2}\left(P G E_{2}\right)$ on luteal function of unilaterally ovariectomized ewes. Prostaglandins Med., 6, 389-401.

MALASSINE A., FERRE F., 1979. $\Delta^{5}, 3 \beta$-hydroxysteroid dehydrogenase activity in cat placental labyrinth : evolution during pregnancy, subcellular distribution. Biol. Reprod., 21, 965-971.

MARCUS G. J., 1981. Prostaglandin formation by the sheep embryo and endometrium as an indication of maternal recognition of pregnancy. Biol. Reprod., 25, 56-64.

MARTAL J., DJIANE J., 1977. The production of chorionic somatomammotrophin in sheep. J. Reprod. Fert., 49, 285-289.

MARTAL J., LACROIX M. C., LOUDES C., SAUNIER M., WINTENBERGER-TORRES S., 1979. Trophoblastin, an antiluteolytic protein present in early pregnancy in sheep. J. Reprod. Fert., 56, 63-73.

MASLAR I. A., RIDDICK D. H., 1979. Prolactin production by human endometrium during the normal menstrual cycle. Am. J. Obst. Gynec., 135, 751-754.

MEAD R. A., 1981. Delayed implantation in mustelids, with special emphasis on the spotted skunk. J. Reprod. Fert., suppl. 29, 11-24.

MEAD R. A., SWANNACK A., 1978. Effects of hysterectomy on luteal function in the western spotted skunk (Spilogale putorius latifrons). Biol. Reprod., 18, 379-383.

MEDNICK D. L., BARLEY M. S., GESCHWIND I. I., 1980. Regulation of progesterone secretion by $\mathrm{LH}$ and prolactin during the first half of pregnancy in the mouse. J. Reprod. Fert., 60, 201207.

MILLER M. M., O'MORCHOE C. C. C., 1982. Decidual cell reaction induced by prostaglandin $F_{2 \alpha}$ in the mature oophorectomized rat. Cell Tiss. Res., 225, 189-199.

MITCHELL J. A., GARRIS D. R., 1978. Deciduoma formation in response to uterine trauma in the guinea pig. Biol. Reprod., 19. 1135-1141.

MOELJONO M. P. E., THATCHER W. W., BAZER F. W., FRANK M., OWENS L. J., WILCOX C. J., 1977. A study of prostaglandin $F_{2 \alpha}$ as the luteolysin in swine : characterization and compari- 
son of prostaglandin $F$, estrogens and progestin concentrations in utero-ovarian vein plasma of non pregnant and pregnant gilts. Prostaglandins, 14, 543-555.

MØLLER O. M., 1973a. Progesterone concentrations in the peripheral plasma of the blue fox (Alopex lagopus) during pregnancy and the oestrous cycle. J. Endocr., 59, 429-436.

MØLLER O. M., 1973b. The progesterone concentrations in the peripheral plasma of the mink (Mustela vison) during pregnancy. J. Endocr., 56, 121-132.

MØLLER O. M., 1974a. Effects of ovariectomy on the plasma progesterone and maintenance of gestation in the blue fox, Alopex lagopus. J. Reprod. Fert., 37, 141-143.

MØLLER O. M., 1974b. Plasma progesterone before and after ovariectomy in unmated and pregnant mink, Mustela vison. J. Reprod. Fert., 37, 367-372.

MOOR R. M., ROWSON L. E. A., 1966. The corpus luteum of the sheep : effect of the removal of embryos on luteal function. J. Endocr., 34, 497-502.

NEILL J. D., JOHANSSON E. D. B., KNOBIL E., 1969. Failure of hysterectomy to influence the normal pattern of cyclic progesterone secretion in the rhesus monkey. Endocrinology, 84, 464465.

NEILL J. D., KNOBIL E., 1972. On the nature of the initial luteotropic stimulus of pregnancy in the rhesus monkey. Endocrinology, 90, 34-38.

NETT T. M., McCLELLAN M., NISWENDER G. D., 1976. Effects of prostaglandins on the ovine corpus luteum : blood flow, secretion of progesterone and morphology. Biol. Reprod., 15, 66-78.

NETT T. M., PICKETT B. W., 1979. Effect of diethylstilboestrol on the relationship between LH, PMSG and progesterone during pregnancy in the mare. J. Reprod. Fert, suppl. 27, 465-470.

NORTHEY D. L., FRENCH L. R., 1980. Effect of embryo removal and intrauterine infusion of embryonic homogenates on the lifespan of the bovine corpus luteum. J. anim. Sci., 50, 298302.

NOYES R. W., HERTIG A. T., ROCK J., 1950. Dating the endometrial biopsy. Fertil. Steril., 1, 1-25.

O'SHEA J. D., LEE C. S., 1973. Effects of section of utero-ovarian vascular connections on the duration of pseudopregnancy in the rat. J. Reprod. Fert., 33, 245-253.

PETERSON A. J., FAIRCLOUGH R. J., PAYNE E., SMITH J. F., 1975. Hormonal changes around bovine luteolysis. Prostaglandins, 10, 675-684.

PETERSON A. J., TERVIT H. R., FAIRCLOUGH R. J., HAVIK P. G., SMITH J. F., 1976. Jugular levels of 13,14-dihydro-15-keto-prostaglandin $F$ and progesterone around luteolysis and early pregnancy in the ewe. Prostaglandins, 12, 551-558.

PHILLIPS C. A., POYSER N. L., 1981. Studies on the involvement of prostaglandins in implantation in the rat. J. Reprod. Fert., 62, 73-81.

POPE W. F., MAURER R. R., STORMSHAK F., 1982. Distribution of progesterone in the uterus, broad ligament and uterine arteries of beef cows. Anat. Rec., 203, 245-250.

POPE G. S., GUPTA S. K., MUNRO I. B., 1969. Progesterone levels in the systemic plasma of pregnant, cycling and ovariectomized cows. J. Reprod. Fert., 20, 369-381.

POYSER N. L., 1972. Production of prostaglandins by the guinea-pig uterus. J. Endocr., 54, 147-159.

POYSER N. L., HORTON E. W., 1975. Plasma progesterone levels in guinea-pigs actively immunized against prostaglandin $\mathrm{F}_{2 \alpha^{\prime}}$ hysterectomized or treated with intra-uterine indomethacin. $J$. Endocr., 67, 81-88.

POYSER N. L., MAULE-WALKER F. M., 1979. Antiluteolytic effect of the embryo, $261-292$. In Maternal recognition of pregnancy. Ciba Found. Ser. 64.

QUAGLIARELLO J., GOLDSMITH L., STEINETZ B., LUSTIG D. S., WEISS G., 1980. Induction of relaxin secretion in non pregnant women by human chorionic gonadotropin. J. c/in. Endocr. Metab., 51, 74-77.

RADWANSKA E., BERGER G. S., HAMMOND J., 1979. Luteal deficiency among women with normal menstrual cycles, requesting reversal of tubal sterilization. Obst. Gyn., 54, 189-192.

RANKIN J. C., LEDFORD B. E., JONSSON H. T., BAGGETT B., 1979. Prostaglandins, indomethacin and the decidual cell reaction in the mouse uterus. Bial. Reprod., 20, 399-404.

RAO B., POINTIS G., CEDARD L., 1982. Presence of a chorionic gonadotropin-like factor in mouse placenta cultures during the second half of gestation. J. Reprod. Fert., 66, 341-348. 
ROTCHCHILD I., GIBORI G., 1975. The luteotrophic action of decidual tissue : the stimulating effect of decidualization on the serum progesterone level of pseudopregnant rats. Endocrinology, 97, 838-842.

ROWSON L. E. A., MOOR R. M., 1967. The influence of embryonic tissue homogenate infused into the uterus, on the life-span of the corpus luteum in the sheep. J. Reprod. Fert., 13, 511516.

SAKSENA S. K., LAU I. F., CHANG M. C., 1976. Relationship between oestrogen, prostaglandin $\mathrm{F}_{2 \alpha}$ and histamine in delayed implantation in the mouse. Acta endocr., 81, 801-807.

SANANES N., BAULIEU E. E., LE GOASCOGNE C., 1976. Prostaglandin(s) as inductive factor of decidualization in the rat uterus. Mol. cell. Endocr., 6, 153-158.

SANANES N., BAULIEU E. E., LE GOASCOGNE C., 1981. A role for prostaglandins in decidualization of the rat uterus. J. Endocr., 89, 25-33.

SATOH K., KAWAI Y., MITSUHASHI N., KINOSHITA K., SAKAMOTO S., 1980. Prostaglandin F $2 \alpha$ metabolites in plasma and urine during pseudopregnancy in the rabbit. Am. J. Obst. Gynec., 138, 748-754.

SAUNDERS P. T. K., ZIECIK A. J., FLINT A. P. F., 1980. Gonadotrophin-like substance in pig placenta and embryonic membranes (abstr.). J. Endocr., 85, 25P.

SAXENA B. B., HASAN S. H., HAOUR F., SCHMIDT-GOLLWITZER M., 1974. Radioreceptor assay of human chorionic gonadotropin : detection of early pregnancy. Science, 184, 793795.

SCHAMS D., HOFFMANN B., FISCHER S., MARZ E., KARG H., 1972. Simultaneous determination of $\mathrm{LH}$ and progesterone in peripheral bovine blood during pregnancy, normal and corticoidinduced parturition and the postpartum period. J. Reprod. Fert., 29, 37-48.

SCHIRAR A., MARTINET J., 1982. Postpartum ovarian activity and its interaction with the uterus in resuming cyclic activity postpartum. Curr. Top. vet. Med. anim. Sci., 20, 67-94.

SCHMIDT A. M., NADAL L. A., SCHMIDT M. J., BEAMER N. B., 1979. Serum concentrations of oestradiol and progesterone during the normal oestrous cycle and early pregnancy in the lion (Panthera /eo). J. Reprod. Fert., 57, 267-272.

SCHULZ K. D., GEIBER W., DEL POZO E., KÜNZIG H. J., 1978. Pattern of sexual steroids, prolactin, and gonadotropic hormones during prolactin inhibition in normally cycling women. Am. J. Obst. Gynec., 132, 561-566.

SEAL U. S., PLOTKA E. D., PACKARD J. M., MECH L. D., 1979. Endocrine correlates of reproduction in the wolf. I. Serum progesterone, estradiol and $\mathrm{LH}$ during the estrous cycle. Biol. Reprod., 21, 1057-1066.

SHAIKH A. A., BIRCHALL K., SAKSENA S. K., 1973. Steroids in the ovarian venous plasma and F prostaglandins in the peripheral plasma during pseudopregnancy and days 1-9 of pregnancy in the golden hamster. Prostaglandins, 4, 17-30.

SHILLE V. M., KARLBOM I., EINARSSON S., LARSSON K., KINDAHL H., EDQVIST L. E., 1979. Concentrations of progesterone and 14-keto-13, 14-dihydroprostaglandin $F_{2 \alpha}$ in peripheral plasma during the estrous cycle and early pregnancy in gilts. Zbl. Vet. Med. A, 26, 169-181.

SINGH E. J., BACCARINI I. M., ZUSPAN F. P., 1975. Levels of prostaglandins $F_{2 \alpha}$ and $E_{2}$ in human endometrium during the menstrual cycle. Am. J. Obst. Gyn., 121, 1003-1006.

SMITH M. S., McDONALD L. E., 1974. Serum levels of luteinizing hormone and progesterone during the estrous cycle, pseudopregnancy an pregnancy in the dog. Endocrinology, 94, 404-412.

SOARES M. J., COLOSI P., TALAMANTES F., 1982. The development and characterization of a homologous radioimmunoassay for mouse placental lactogen. Endocrinology, 110, 668-670.

SOKOLOWSKI J. H., 1971. The effects of ovariectomy on pregnancy maintenance in the bitch. Lab. anim. Sci., 21, 696-699.

SQUIRES E. L., GINTHER O.. J., 1975. Follicular and luteal development in pregnant mares. J. Reprod. Fert., suppl. 23, 429-433.

STABENFELDT G. H., HUGHES J. P., WHEAT J. D., EVANS J. W., KENNEDY P. C., CUPPS P. T., 1974. The role of the uterus in ovarian control in the mare. J. Reprod. Fert., 37, 343-351.

StABENFELDT G. H., KINDAHL H., HUGHES J. P., NEELY D. P., LIU I., PASCOE D., 1981. Control of luteolysis in the mare. Acta vet. scand., suppl. 77, 159-170. 
STELLFLUG J. N., MUSE P. D., EVERSON D. O., LOUIS T. M., 1981. Changes in serum progesterone and estrogen of the nonpregnant coyote during the breeding season. Proc. Soc. exp. Biol. Med., 167, 220-223.

TABARELLI M., KOFLER R., SCHWARZ S., WICK G., 1982. Rat placental hormones : attempts for identification of rat chorionic gonadotropin and rat placental lactogen by in vivo experiments. Acta endocr., 99, 288-294.

TERRANOVA P. F., 1975. Prolonged production of ovarian progesterone in pseudopregnant hamsters bearing deciduomata. Proc. Soc. exp. Biol. Med., 148, 1111-1113.

THIBAULT C., LEVASSEUR M. C., 1979. La fonction ovarienne chez les mammifères. Masson, Paris.

THORBURN G. D., COX R. I., CURRIE W. B., RESTALL B. J., SCHNEIDER W., 1973. Prostaglandin $\mathrm{F}$ and progesterone concentrations in the utero-ovarian venous plasma of the ewe during the oestrous cycle and early pregnancy. J. Reprod. Fert., suppl. 18, 151-158.

TORRES C. A. A., FIRST N. L., 1975. Effect of surgical separation of uterus and ovaries on estrous cycle length in swine. J. anim. Sci, 40, 905-910.

TU B. K., 1978. Effect of hCG on human corpus luteum of menstruation and early gestation. Endocr. japon., 25, 569-574.

VERHAGE H. G., BEAMER N. B., BRENNER R. M., 1976. Plasma levels of estradiol and progesterone in the cat during polyestrus, pregnancy and pseudopregnancy. Biol. Reprod., 14, 579-585.

VERNON M. W., ZAVY M. T., ASQUITH R. L., SHARP D. C., 1981. Prostaglandin $F_{2 \alpha}$ in the equine endometrium : steroid modulation and production capacities during the estrous cycle and early pregnancy. Biol. Reprod., 25, 581-589.

WADE-SMITH J., RICHMOND M. E., MEAD R. A., TAYLOR H., 1980. Hormonal and gestational evidence for delayed implantation in the striped skunk, Mephitis mephitis. Gen. Comp. Endocr., 42, 509-515.

WEEMS C. W., 1979. Prostaglandin F in uterine and ovarian compartments and in plasma from the uterine vein, ovarian artery and vein, and abdominal aorta of pseudopregnant rats with and without deciduomata. Prostag/andins, 17, 873-890.

WEEMS C. W., HUECKSTEADT T. P., SJAHLI H., LAVELLE P., 1979. Effects of PGE 1 or PGE on luteal function in pseudopregnant rats. Prostaglandins, 17, 891-901.

WEEMS C. W., PEXTON J. E., BUTCHER R. L., INSKEEP E. K., $1975 . \quad$ Prostaglandins F in uterine tissue and venous plasma of pseudopregnant rats : effect of deciduomata. Biol. Reprod., 13, 282-288.

WIDE L., HOBSON B., 1978. Chromatographic studies on a chorionic gonadotropic activity in the placenta of the rat, mouse and hamster. Uppsala J. med. Sci, 83, 1-6.

WIDE L., WIDE M., 1979. Chorionic gonadotrophin in the mouse from implantation to term. J. Reprod. Fert., 57, 5-9.

WIMSATT W. A., 1952. Some aspects of the comparative anatomy of mammalian placenta. Am. J. Obst. Gynec., 84, 1568-1594.

${ }^{*}$ ) Note added in proof: SOARES, COLOSI, OGREN and TALAMANTES (1983, Endocrinology, 112, 1313-1317) showed the existence of uterine « prolactin » in mouse ; BASURY, JAPPE and GIBORI (1983, Biol. Reprod., 28, 551-556) confirmed its luteotrophic role in rat. 